Wiestaw WIŚNIEWOLSKI

\title{
FECUNDITY OF CATFISH (SILURUS GLANIS L.) FROM THE RIVERS VISTULA AND BUG
}

PŁODNOŚĆ SUMA (SILURUS GLANIS L.) Z WISŁY I BUGU

Inland Fisheries Institute, Olsztyn

Department of River Fisheries at Żabieniec

\begin{abstract}
Analyses were made of the fecundity of catfish from the rivers Vistula and Bug. Oocytes were counted, measured, and divided into groups depending on the presence of the corpus luteum. No statistically significant differences were found as to the oocy te numbers in the samples taken from different gonad sections. Lutcal oocytes differed considerably as to their size, these differences being observed between particular females as well as for the same gonads. Number of the luteal oocy tes depended on the fish weight and body length. The respective coefficients of correlation were 0.92 and 0.88 , and these dependencies were expressed in a mathematical form.
\end{abstract}

\section{INTRODUCTION}

The first information on the fecundity of European catfish (Silurus glanis L.) were given by Antipa as early as 1909 (Brujenko 1967) and referred to lower Danube. A bulk of information can be found in Soviet literature: fecundity of catfish in different regionsof the country has been extensively delt with (Bugaj 1966, Brujenko 1967, Lysenko 1976). An amount of information from other countries is also available (Suchomelova 1952, Hochman 1967 a, Ristic 1972). Usually, fecundity is described as the number of the oocytes in relation to female weight or length. A paper by Sichక̌abekov (1978) is an exeptional one, as it describes the development of catfish gonads in the annual cycle.

The aim of my paper was to determine the fecundity of catfish from Vistula and Bug rivers. Determinations were made on the basis of the number of luteal oocy tes in the ovaries, with attention given to the representativeness of samples taken from different parts of the gonad. 


\section{MATERIAL AND METHOD}

Ovaries were collected from 15 females of total length (lt) varying from $84 \mathrm{~cm}$ to $175 \mathrm{~cm}$, weighing from $4.2 \mathrm{~kg}$ to $36.0 \mathrm{~kg}$. The fishes were caught in 1979-1981 in the rivers Vistula and Bug. It was assumed beforehand that a relationship should be established between fish fecundity and their size. Since it was not possible to collect many fishes, an attempt was made to select the females representing as many size-classes as possible. The fishes were measured up to $1 \mathrm{~cm}$ and weighed to $100 \mathrm{~g}$. The gonads were preserved in 4\% formalin (Brylińska and Bryliński 1972). Peserved ovaries were weighed up to $1 \mathrm{~g}$. Samples of the ovaries $(0.5$ to $1.0 \mathrm{~g})$ were taken for the determination of fish fecundity.

Three fishes were used to establish the representativeness of the samples taken from different gonad sections. In this case, samples were taken from both gonads, from their surface and internal layer as well as front, middle and back section (Fig. 1). For other females, three samples were taken from the surface layer of the right ovary.

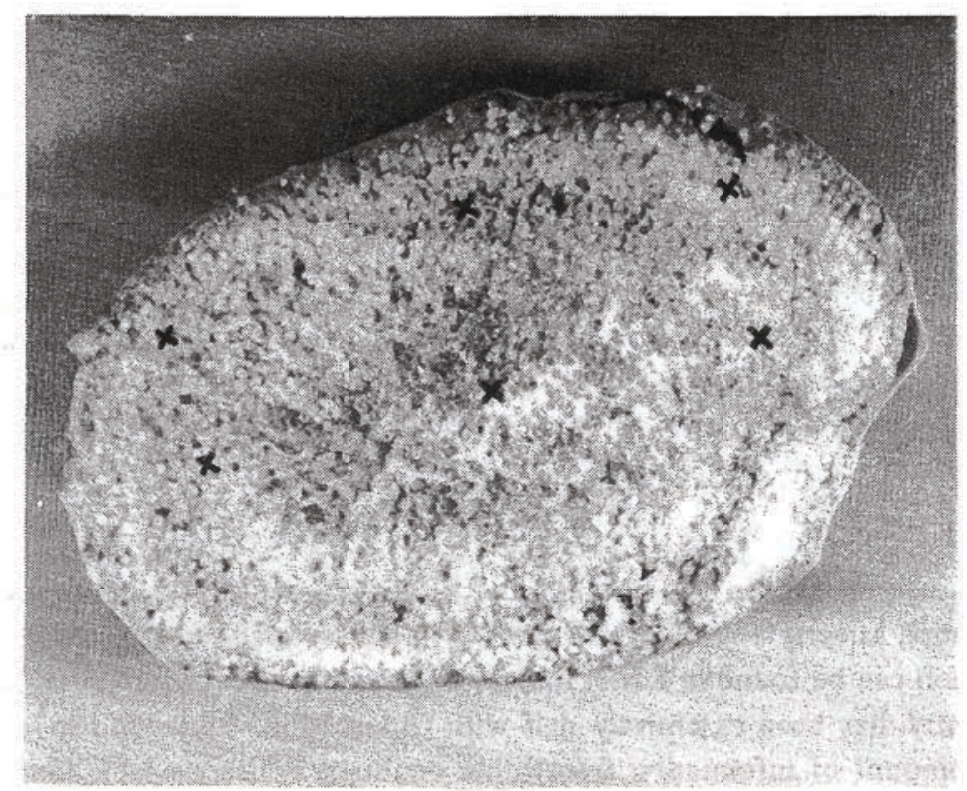

Fig. 1. Section of a carfish ovary. Crosses - places of sample collection. (phot. J. Nabiałek).

Each sample was weighed up to $0.001 \mathrm{~g}$ and then examined under a stereoscopic microscope (ocular 12, magn. 1.6). The oocytes were divided into luteal (yellow) and white ones (Asmanin and Pobgornyj 1968, Śchsabekov 1978). Presence of the corpus luteum was used as a criterion of this division.

In 36 samples taken from the 3 mentioned females (from both gonads, see Fig. 1) all luteal and white oocytes have been counted and measured. In other samples, only the luteal oocytes were counted and measured, their longer diameter being taken into consideration. 


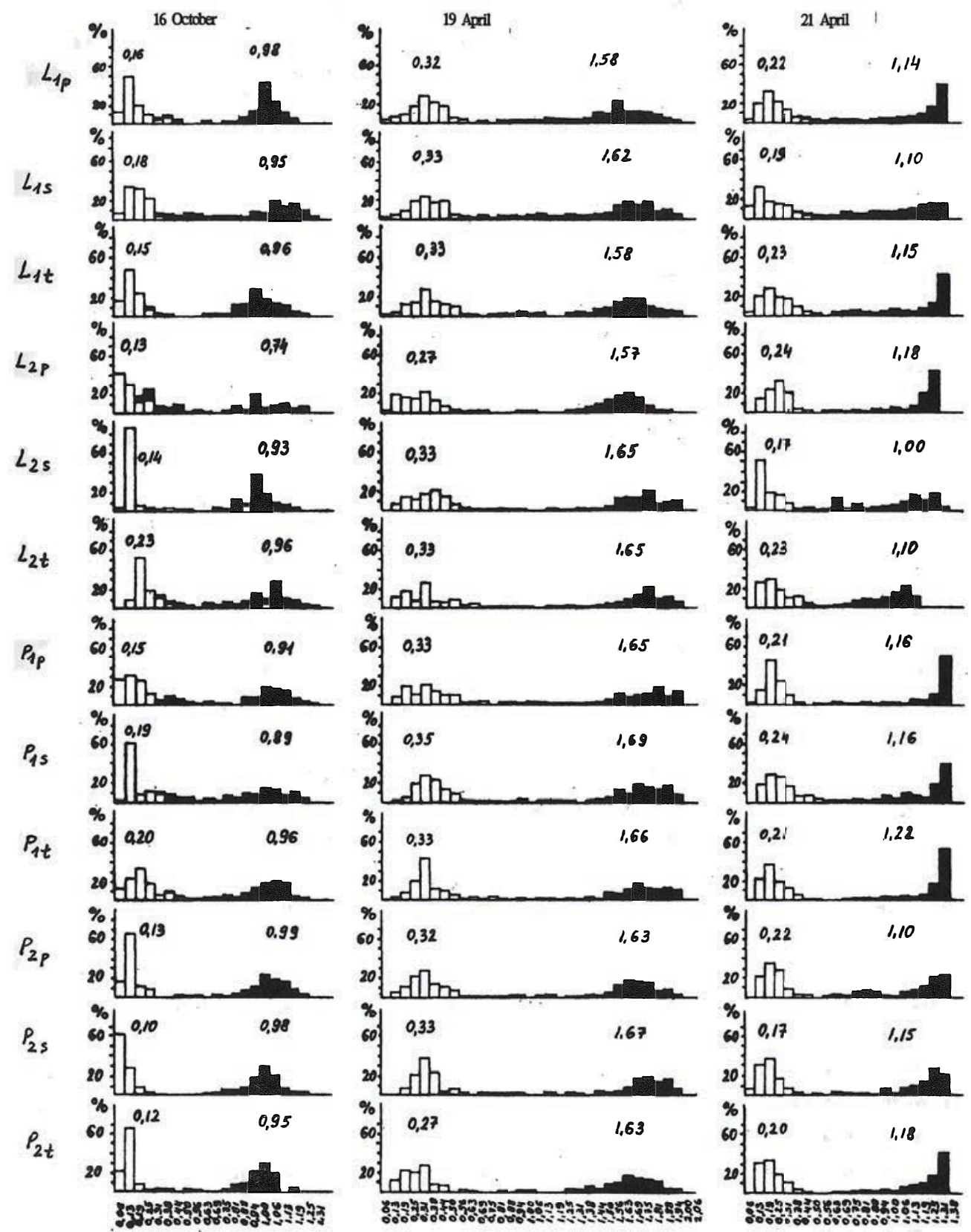

Fig. 2. Distribution of oocyte size in the gonads of three cattish females caught on 16 October,

19 April and 21 April

L - left gonad, P - right gonad, 1 -- surface layer, 2 - internal layer, $\mathrm{p}$ - front part of the gonad, $s$ - middle part of the gonad, $t$ - back part of the gonad (see Fig. 1). 
Significance of the differences between the samples taken from different gonads and their sections (the three mentioned fishes, see Fig. 1) were established with univariate analysis of variance. Regression analysis was used to establish the dependence between the number of yellow oocytes in the gonads and the fish length and weight.

\section{RESULTS}

Cross-sections of the ovaries (Fig. 1) suggested that there might have been considerable differences between its various sections as to the number of the oocytes present. The results of the analysis presented in Fig. 2 do not confirm this suggestion; patterns of the oocyte distribution are fairly similar in all samples taken from different sections of the gonads.

Two groups of the oocytes were present in all samples: white and yellow (luteal), represented by light and dark bars in Fig. 2. Similarity in the oocyte size in the two groups could be well observed for the fish caught in autumn. It was most prominent for the oocyte diameter of $0.13 \mathrm{~mm}$ to $0.50 \mathrm{~mm}$. As regards the fishes caught in spring, these similarities tended to disappear. At the same time the oocytes increased (see average values above the bars) suggesting that yellow oocy tes grew more rapidly.

Oocytes in the phase of corpus luteum formation were observed in the gonads of the fish caught on 16 October as well as those caught on 19 and 21 April. This suggets that the gonads of all females were in the IVth stage of development (Pliszka 1964, Šichšabekov 1978).

Similarities in the patterns of the oocyte size distribution (Fig. 2) were confirmed by statistical tests. Analysis of variance gave $\mathrm{F}_{\text {emp }}=0.08$, this value being lower than $F_{\text {tab }}=(1$ stech, $q=0.01)=3.11$. Thus, the differences between the samples were not significant statistically. Consequently, it can be assumed that different parts of the gonads are equally representative as regards the estimates of fecundity, and that it is not necessary to take so many samples as seen in Fig. 2.

Table 1 presents diameter and number of the luteal (yellow) oocytes present in the gonads of the females caught in differentmonths. Size of the oocytes varied but tended to increase as the spawning period approached. On the average, this diameter was from $0.96 \mathrm{~mm}$ for the fishes caught in October to $1.67 \mathrm{~mm}$ for the fishes caught in May. However, the range of variability was rather wide; for the fishes mentioned above it was 0.25 to $1.31 \mathrm{~mm}$ and $0.50 \mathrm{~mm}$ to $2.50 \mathrm{~mm}$ (for other fishes see Tab. 1).

Also number of the luteal oocytes in the gonads varied considerably. It ranged from 243 to 1114 per $1 \mathrm{~g}$ of the gonad. Totally, number of the yellow oocytes in particular females amounted to from 34.7 thousand in a female weighing $5.3 \mathrm{~kg}$ to 788.0 thousand in a female weighing $36.0 \mathrm{~kg}$.

Dependence of the number of luteal (yellow) oocytes on fish weight and length is presented in Fig. 3. It is expressed by the regresion: 
Absolute fecundity of catfish expressed as the number of the luteal

(yellow) oocytes in the ovaries of females caught in different months

\begin{tabular}{|c|c|c|c|c|c|c|c|}
\hline \multirow{2}{*}{ Month } & \multirow{2}{*}{$\mathbf{N}$} & $\overline{\mathrm{L}}$ & $\overline{\mathrm{W}}$ & $\overline{\mathrm{W}} \mathrm{g}$ & $\overline{\mathrm{Sr}}$ & $\bar{n}$ & $\overline{\mathrm{F}} \mathbf{a}$ \\
\hline & & \multicolumn{6}{|c|}{ range } \\
\hline October & 1 & 175 & 36.0 & 1.645 & $\begin{array}{c}0.96 \\
(0.25-1.31)\end{array}$ & 479 & 788000 \\
\hline $\begin{array}{l}\text { February- } \\
\text { March }\end{array}$ & 3 & $\begin{array}{c}111 \\
(100-118)\end{array}$ & $\begin{array}{c}8.7 \\
(6.5-10.5)\end{array}$ & $\begin{array}{c}0.287 \\
(0.158-0.425)\end{array}$ & $\begin{array}{c}1.36 \\
(0.50-2.06)\end{array}$ & $\begin{array}{c}639 \\
(575-688)\end{array}$ & $\begin{array}{c}182567 \\
(108700-278000)\end{array}$ \\
\hline April & 3 & $\begin{array}{c}114 \\
(100-132)\end{array}$ & $\begin{array}{c}13.0 \\
(7.0-23.0)\end{array}$ & $\begin{array}{c}0.396 \\
(0.058-0.907)\end{array}$ & $\begin{array}{c}1.36 \\
(0.44-1.94)\end{array}$ & $\begin{array}{c}795 \\
(477-1114)\end{array}$ & $\begin{array}{c}225067 \\
(64600-432600)\end{array}$ \\
\hline May & 8 & $\begin{array}{c}107 \\
(84-157)\end{array}$ & $\begin{array}{c}9.6 \\
(4.2-24.0)\end{array}$ & $\begin{array}{c}0.554 \\
(0.108-1.682)\end{array}$ & $\begin{array}{c}1.67 \\
(0.50-2.50)\end{array}$ & $\begin{array}{c}371 \\
(243-588)\end{array}$ & $\begin{array}{c}161588 \\
(34700-408700)\end{array}$ \\
\hline
\end{tabular}

\footnotetext{
$\mathrm{N} \quad$ - number of females

$\overline{\mathrm{L}} \quad$ - average length (lt) in $\mathrm{cm}$

$\overline{\mathrm{W}} \quad$ - average body weight in $\mathrm{kg}$

$\overline{\mathrm{W}} \mathrm{g} \quad$ - average gonad weight in $\mathrm{kg}$

$\bar{S} r \quad$ - average size of luteal oocy tes in $\mathrm{mm}$

$\overline{\mathrm{n}} \quad$ average number of luteal oocytes in $1 \mathrm{~g}$ of gonad

$\mathrm{Fa} \quad-$ average absolute fecundity
} 
Absolute fecundity of catfish according to different authors

\begin{tabular}{|c|c|c|c|c|c|c|c|}
\hline Author & $\mathrm{N}$ & $\mathrm{L}$ & W & $\mathrm{Sr}$ & $\mathrm{n}$ & $\mathrm{Fa}$ & Fish origin \\
\hline Biełyj 1966 & 29 & - & $3.100-15.270$ & - & $179-508$ & $38592-306240$ & $\begin{array}{l}\text { Dnieper, Kochowski } \\
\text { Dam Reservoir }\end{array}$ \\
\hline Brujenko 1967 & 80 & $68-236$ & $2.5-76.0$ & $2.7-3.0$ & - & $11810-1380000$ & Danube River \\
\hline Bugaj 1966 & 15 & $55-132$ & $1400-22000$ & - & $135-499$ & $27400-384500$ & Dnieper River \\
\hline Hochman 1967a & $=$ & $80-160$ & $4.70-29.25$ & - & $137.7-305.5$ & $42822-391411$ & $\begin{array}{l}\text { Wranowski Dam } \\
\text { Reservoir }\end{array}$ \\
\hline Ristić 1972 & 1 & - & 12668 & 3.0 & 198 & 356400 & Danube River \\
\hline Sichふ̌abekov 1978 & - & $42-193$ & $1.2-41.3$ & $2-3$ & - & $14600-285000$ & Waters of Dagestan \\
\hline Suchomelova 1952 & 11 & $88-129$ & - & - & $130-730$ & $61400-249300$ & Vlteva River \\
\hline
\end{tabular}

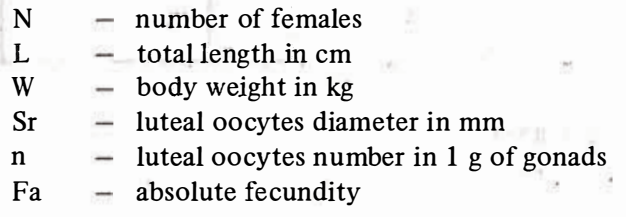




$$
\mathrm{F}_{\mathrm{a}}=-13.2070+19.6969 \mathrm{~W}
$$

where $\mathrm{W}-$ fish weight, and by the regresion:

$$
\mathrm{F}_{\mathrm{a}}=0.0000382 \mathrm{~L}^{3.2324}
$$

where $\mathrm{L}$ - fish length.

Luteal oocyte numbers depended on both fish weight and length, the respective correlation coefficients being 0.92 and 0.88 .

\section{DISCUSSION OF THE RESULTS AGAINST THE LITERATURE}

The analysed gonads contained from 34.7 thousand to 788.0 thousand luteal (yellow) oocytes at fish weight of from $5.3 \mathrm{~kg}$ to $36.0 \mathrm{~kg}$ and length from $84 \mathrm{~cm}$ to $175 \mathrm{~cm}$. Number of the luteal oocytes in $1 \mathrm{~g}$ of the ovary varied from 243 to 1114 , their diameter being from $0,25 \mathrm{~mm}$ to $2.50 \mathrm{~mm}$. Absolute fecundity of catfish in Poland, as calculated from the luteal oocytes (Moroz 1968, Asmanin and Pobgornyj 1968, Cigirinskij 1970, Brylińska et al. 1979) was similar to that found for this fish in the catchment area of Black and Caspian Sea (Tab. 2). On the other hand, considerable differences were found as regards the egg number in $1 \mathrm{~g}$ of the ovary (compare Table 1 and 2). These differences may be explained by the period of fish sampling. According to Suchomelova (1952) oocyte numbers found in catfish after the spawning in July (new generation which will spawn next year) was higher than in the fishes caught in May, before the spawning period. Annual changes of the number of luteal oocytes were also observed by Asmanin and Pobgornyj (1968). These authors studied absolute fecundity of common crucian carp (Carassius carassius) and found that it amounted to 22 thousand in April, 24 thousand in September and 18 thousand in October, while in case of gold fish (Carassius aureatus gibelio) it amounted to 48-60 thousand eggs in April and to 38-54 thousand in June. Also absolute fecundity of sea trout (Salmo trutta $m$-trutta) was by $14 \%$ lower in autumn, during spawning period, than in July, during fish migration. The differences were statistically significant (Domagała 1986). In my material the lowest numbers of the luteal oocytes were usuaily observed in the fishes caught in May, i.e. just before spawning.

Sichsabekov (1978) stated that peak of vitellogenesis in catfish was observed in summer (July-August), and that the females passed winter with the ovaries in the IVth stage of development. The same was also observed in my studies. Supplementary vitellogenesis took place in spring, and the oocytes attained final size of 2-3 mm in April. In Dagestan (USSR) catfish spawnd at the end of May, but in Polish conditions in mid-June. This explains greater variability of the oocyte size and their smaller diameter in the same periods (Tab. 1). The same is also indirectly confirmed by Horoszewicz (1971). She stated that asynchronic development of the occytes was observed in catfish as late as 10 days before spawning, whereas in other fishes of the same type of spawning (eggs laid in one partion only) asynchronic development of the oocytes was observed only in the initial stages of gonad maturation. The same was observed by Hochman $(1967,1970)$ 
who àlso found that a new group of smaller oocytes was formed prior to spawning, and that these were designated for the fish reproduction in the next year. The same author stated that part of the developed oocytes which had not been laid was not resorbed after the fish spawning and might have been preserved for the next spawning.

It should be mentioned that I had no catfish gonads from mid-June, i.e. from the period prior to spawning, when the oocy te grow th was already completed, nor from July, i.e. from the period directly after spawning. Moreover, I was able to collect a limited number of catfish females. Consequently, it was not possible to fully determine the oocyte variability. To do this, more material must be collected in the coming years.
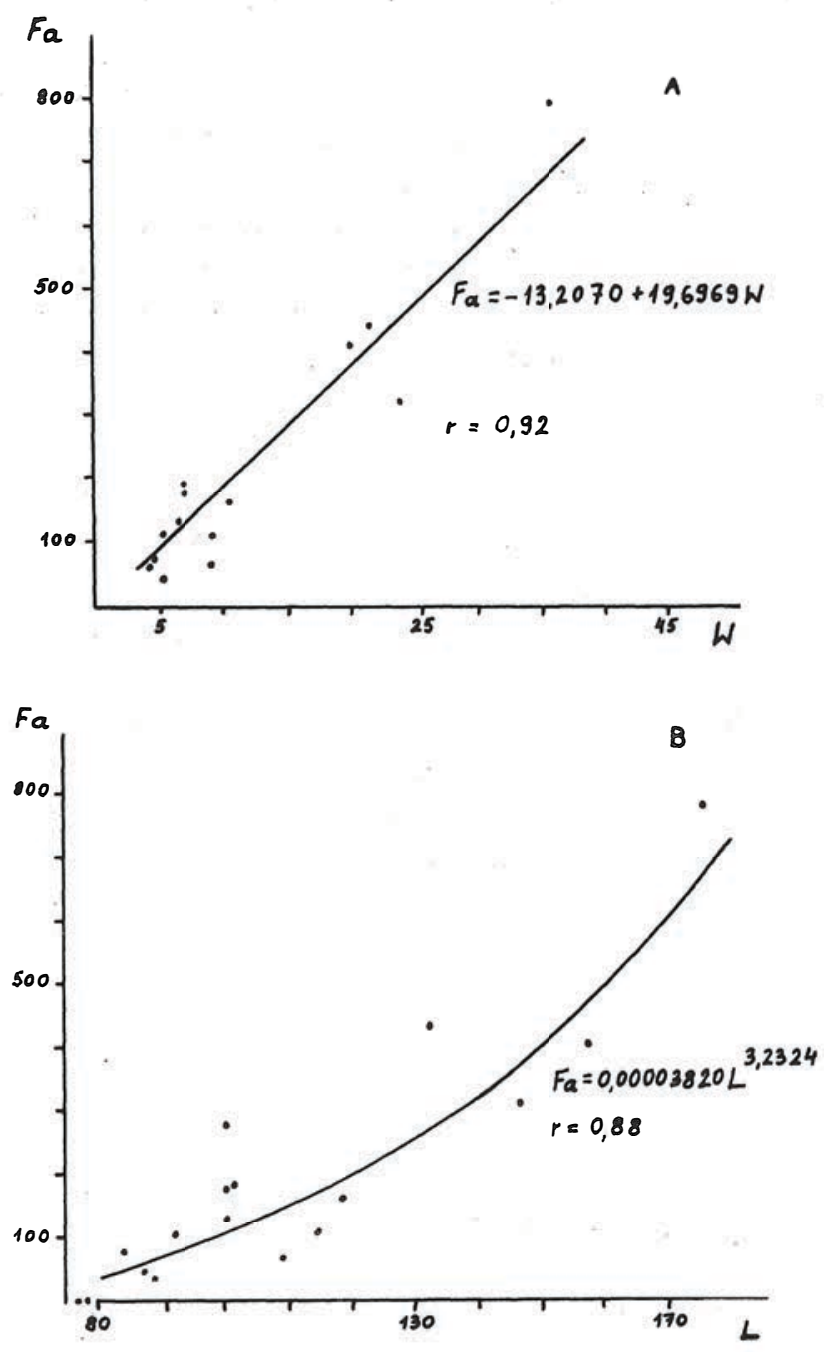

Fig. 3. Dependence between number of the luteal (yellow) oocytes and fish weight (A) and length (B). $\mathrm{l}$ a - absolute tecundity, $\mathrm{W}$ - body weight in $\mathrm{kg}, \mathrm{L}$ - total length in $\mathrm{cm}$. 


\section{CONCLUSIONS}

No significant differences were observed as to the oocyte numbers in the samples collected from different parts of catfish gonads. The calculated functions are generally similar to those given in the literature. Hence, it may be concluded that they describe acuratelly the fecundity of catfish for the fishes 84 to $175 \mathrm{~cm}$ in length and 4 to $36 \mathrm{~kg}$ in weight.

\section{REFERENCES}

Asmanin L.P., Pobgornyj M.J., 1968: Osobennosti plodovitosti karasej Carassius carassius (L), C.auraetus gibelio (Bloch). Vopr. Ichtiol. 8,2: 266-273 (in Russian)

Biełyj M.D., 1966: Nekotoryje nabljudenja za somom Kachowskogo Wodochranilišča. Ryb. Choz. 11:22. (in Russian)

Brujenko W.P., 1967: Plodovitost soma nizowjej Dunaja. Gidrobiol. Żurn. 3,1: 83-85 (in Russian)

Brylińska M., Bryliński E., 1972: Methods of determining fish fecundity as exemplified by brea (Abramis brama Linnaeus). Rocz. Nauk Rol., 94-H -2: 7-37.

Brylińska M., Bryliński E., Mieczykowski K., 1979: The effect of individual features on tench (Tinca tinca) fecundity in several lakes of Mazurian and Chełmińsko-Dobrzyński lake lands. Rocz. Nauk. Rol. H-99: 25-54.

Bugaj K.S., 1966: Materiały po biologii soma nizowjew Dniepra. Gibrob. Żurn. 2,1' 49-54. (in Russian)

Cigirinskij A.J., 1970: Charakter owogeneza i plodowitost japonskoj stawridy Trachurus japonicus (Temminek et Schlegel). Vopr. Ichtiol. 10:1005-1011. (in Russian).

Domagała J., 1986: Oogenesis in sea trout (Salmo trutta L.) from the rivers of West Pomerania agains their growth rate, with special reference given to the relationship smolt-adult fish. AR Szczecin.

Hochman L., 1967: Fertility in the sheatfish (Silurus glanis L.). Acta Univ. Agric. Fac. Agron. 15,2: $333-355$.

Hochman L., 1970‘ Význam klimatických podminek płi vytěru sumce. Acta Univ. Agric. Brno, A,3: 471-477.

Horoszewicz L., 197 1: Catfish. PWRiL, Warszawa.

Lysenko H.F., 1976: K woprosu o rozmnożenii soma ozera Bałchał̌. Rybochozjajstwiennyje izu飞enije Wnutrennych Wodojemow. Sbornik 7: 12-17 (in Russian).

Moroz V.N., 1968: Biologija lina (Tinca tinca L.) Kilijskoj delty Dunaja. Vopr.Ichtiol. 8: 106-115. (in Russian).

Pliszka F., 1964: Biologia ryb. [Fish biology ]. PWRiL. Warszawa.

Ristið̌ M.D., 1972: Som (Silurus glanis L.). Biologija, rasprostranjenje i mogučnosti njegovog uzgoja u ribnjacima Jugoslavije. Rib. Jugosl. 6: 129-139. (in Yugoslavian).

Sichక̌abekov M.M., 1978: Połovye cikły soma Silurus glanis L., ̧̌̌uki Esox lucius L., okunia Perca fluviatilis L. i sudaka Lucioperca lucioperca (L). Vopr. Ichtiol. 18,3: 507-5 18. (in Russian).

Suchomelova K., 1952: Množstvi jiker sumce obecneho. Českoslov. Rybar. 114. (in Czech). 
Wiesław Wiśniewolski

\section{PŁODNOŚĆ SUMA (SILURUS GLANIS L.) Z WISŁY I BUGU}

\section{STRESZCZENIA}

Analizowano płodność 15 samic suma o długośści (It) od $84 \mathrm{~cm}$ do $175 \mathrm{~cm}$ i ciężarze od $4,2 \mathrm{~kg}$ do $36,0 \mathrm{~kg}$, złowionych w Wiśle i Bugu. Gonady wypreparowywano i umieszczano w 4\% roztworze formaliny. Formalinowane gonady ważono z dokładnością do $1 \mathrm{~g}$. Również wtedy z różnych ich miejsc pobierano próbki do oznaczenia płodności. Ważono je $\mathrm{z}$ dokładnością do $0,001 \mathrm{~g}$. Oocyty dzielono w nich na: posiadające ciałko żółtkowe i nieposiadające go. Nie stwierdzono statystycznie istotnych różnic $\mathrm{w}$ liczebności oocytów $\mathrm{w}$ próbkach pobranych $\mathrm{z}$ różnych części gonad. Zakres zmienności wielkości oocy tów żółtkowych był duży, zarówno pomiędzy poszczególnymi samicanii, jak i w gonadzie każdej z nich. Płodność absolutna wahała się od 34,7 tys. do 788,0 tys. sztuk oocytów żółtych u ryb ważących odpowiednio od $5,3 \mathrm{~kg}$ do $36,0 \mathrm{~kg}$. Silnie związana ona była $\mathrm{z}$ ciężarem i długością, co opisano matematy cznymi funkcjami. Współczynniki korelacji wynosiły 0,92 względem ciężaru i 0,88 względem długości.

Author's address:

Received: 87.06.20

Dr Wiesław Wiśniewolski

Insty tut Rybactwa Sródlądowego

Zakład Rybactwa Stawowego Rzecznego

Żabieniec

05-500 Piaseczno

Polska (Poland) 